\title{
Comparative Analysis of Wear for Excavator Bucket Tooth Using Different Materials
}

\author{
Dr. Sabah Khan ${ }^{1}$, Sheikh Mohashin ${ }^{2}$ \\ ${ }^{1,2}$ Mechanical Engineering Department, JMI New Delhi, India
}

\begin{abstract}
The Excavator is used for material handling at mining and construction sites. The bucket teeth of the excavator have to bear heavy dynamic loads of materials like soil, rock, etc. The bucket teeth are subjected to abrasive wear due to the abrasive nature of soil particles. This phenomenon reduces the life of the excavator bucket tooth to $72-120$ working hours. This paper deals with comparative analysis of wear on the basis of volume loss using, for the excavator bucket. The purpose of work is to improve the service life of bucket tooth by decreasing the wear.
\end{abstract}

Keywords: excavator, wear

\section{Introduction}

Mining is the extraction of valuable minerals or other geological materials from the earth from an ore body, lode, vein, seam, reef or placer deposits which forms the mineralized package of economic interest to the miner. The Mining industry in India is a major economic activity which contributes significantly to the economy of India. The GDP contribution of the mining industry varies from $2.2 \%$ to $2.5 \%$ only but going by the GDP of the total industrial sector it contributes around $10 \%$ to $11 \%$. Even mining done on small scale contributes $6 \%$ to the entire cost of mineral production. Indian mining industry provides job opportunities to around 700,000 individuals (1).

Ministry of Mines is responsible for survey, exploration and mining of all minerals, other than natural gas, petroleum, atomic minerals and Coal. Ores extracted during mining include metals, coal, oil shale, gemstones, limestone, dimension stone, rock salt, potash, gravel, and clay. Mining is required to obtain any material that cannot be grown through agricultural processes, or created artificially in a laboratory or factory. Mining in a wider sense includes extraction of any non-renewable resource such as petroleum, natural gas, or even water.Wear related failure in industry can be summarized as (2)-:

\begin{tabular}{|c|c|c|c|c|c|c|}
\hline $\begin{array}{c}\text { Type of } \\
\text { wear }\end{array}$ & $\begin{array}{c}\text { Abrasive } \\
\text { wear }\end{array}$ & $\begin{array}{c}\text { Adhesive } \\
\text { wear }\end{array}$ & $\begin{array}{c}\text { Erosive } \\
\text { wear }\end{array}$ & $\begin{array}{c}\text { Fretting } \\
\text { wear }\end{array}$ & $\begin{array}{c}\text { Corrosive } \\
\text { wear }\end{array}$ & Other \\
\hline failure & $50 \%$ & $15 \%$ & $8 \%$ & $8 \%$ & $5 \%$ & $14 \%$ \\
\hline
\end{tabular}

\section{Theoretical Analysis}

The excavation force required to cut the soil by the excavator bucket tooth has been analyzed in this work to improve the design of the bucket teeth, for different materials. The existing excavator bucket tooth assembly was analyzed for the operational loading conditions for its failure during working.

\section{Calculations:}

\begin{tabular}{|c|c|}
\hline $\begin{array}{l}\text { Material Properties of Tooth (3): } \\
\text { AISI 1045AISI } 1035\end{array}$ & Material properties of tooth: \\
\hline Modulus of elasticity $=205 \mathrm{GPa}$ & Modulus of elasticity $=190-210 \mathrm{GPa}$ \\
\hline Poisson's Ratio $=0.29$ & Poisson's Ratio $=0.27-0.29$ \\
\hline Ultimate Tensile Strength $=670 \mathrm{MPa}$ & Ulimate Tensile Strength $=585 \mathrm{MPa}$ \\
\hline Yield Tensile Strength $=435 \mathrm{MPa}$ & Yield Tensile Strength $=370 \mathrm{MPa}$ \\
\hline Hardness $=210 \mathrm{BHN}$ & Hardness $=183 \mathrm{BHN}$ \\
\hline $\begin{array}{l}\text { Material Properties of Tooth: } \\
\text { AISI 304AISI } 4130\end{array}$ & Material properties of tooth: \\
\hline$\overline{\text { Modulus of elasticity }}=190 \mathrm{GPa}$ & Modulus of elasticity $=205 \mathrm{GPa}$ \\
\hline Poisson's Ratio $=0.29$ & Poisson's Ratio $=0.285$ \\
\hline Ultimate Tensile Strength $=517 \mathrm{MPa}$ & Ultimate Tensile Strength $=560 \mathrm{MPa}$ \\
\hline Yield Tensile Strength $=206 \mathrm{MPa}$ & Yield Tensile Strength $=460 \mathrm{MPa}$ \\
\hline Hardness $=123 \mathrm{BHN}$ & Hardness $=197 \mathrm{BHN}$ \\
\hline
\end{tabular}




\section{International Journal of Science and Research (IJSR)}

ISSN (Online): 2319-7064

Index Copernicus Value (2013): 6.14 | Impact Factor (2015): 6.391

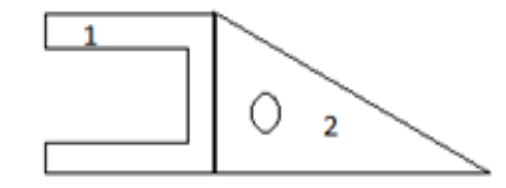

schematic diagram of bucket tooth

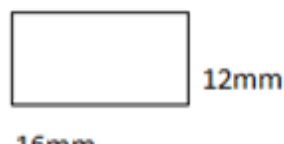

$16 \mathrm{~mm}$

cross section of 2

Figure 1: Tooth geometry

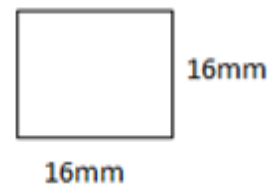

cross section of 1

$\frac{M}{I_{x x}}=\frac{\sigma}{y}$

$\frac{6380000}{374 * 10^{3}}=\frac{\sigma}{30}=\sigma=511.76 \mathrm{MPa}$
$\mathrm{F}=31900 \mathrm{~N}$ and $\mathrm{A}=708 \mathrm{~mm}^{2}$

Then shear stress $=\frac{\text { force }}{\text { area }}$

$\tau=\frac{31900}{708}=\tau=45.05 \mathrm{MPa}$

Wear analysis the analytical wear analysis is carried out for two materials used for fabricating excavator bucket tooth based on Archard's Modified equation for abrasive wear. The amount of volume loss is then compared with the simulation using ANSYS based on creep strain (4)

Consider a modified form of the Archard equation:

$$
\mathrm{W}=\mathrm{K}^{*} \mathrm{~S} \mathrm{C} 2 * \mathrm{R} \mathrm{C} 3
$$

Wear strain as the change in volume divided by the original volume and rewrite the wear equation as

$$
\text { ewr }=\mathrm{C} 1 * \mathrm{~S} \mathrm{C} 2 * \mathrm{R} \mathrm{C} 3 \quad \text { eq } 1
$$

Where $\mathrm{C} 1$ is equal to $\mathrm{K}$ divided by the volume. This strain is similar to volumetric strain which has the form

\section{On the basis of contact stress}

Contact stress is taken half of the ultimate tensile strength

$x \times 2=215.72 * 10^{3} \mathrm{~mm}^{4}$

Now $I_{X X}=I_{x x 1}+I_{x x 2}$

$I_{x x}==374 * 10^{3} \mathrm{~mm}^{4}$

By bending equation

\section{Material I AISI 1045Material II AISI 304}

Contact stress $=0.5 * 670=335 \mathrm{MPa}$

ewr $=\frac{10^{-4}}{0.473} * 335 * 1 * 1=\mathrm{ewr}=70.83 * 10^{-3}$

\section{Material III AISI 1035Material IV AISI 4130}

Contact stress $=0.5 * 585=292.5 \mathrm{MPa}$

Contact stress $=0.5 * 560=280 \mathrm{MPa}$

Then Wear strain

ewr $=\frac{10^{-4}}{0.473} * 292.5 * 1 * 1=\mathrm{ewr}=61.83 * 10^{-3} \mathrm{ewr}=\frac{10^{-4}}{0.473} * 280 * 1 * 1=59.19 * 10^{-3}$

Where $\mathrm{S}$ induced stress, $\mathrm{R}$ repetition of load, $\mathrm{C} 2 \& \mathrm{C} 3$ are constant

\section{$\underline{\text { Simulation }}$}

\begin{tabular}{|c|c|}
\hline \multicolumn{2}{|c|}{ Statistics } \\
\hline Nodes & 42353 \\
\hline Elements & 24256 \\
\hline Mesh Metric & None \\
\hline Suppressed & No \\
\hline Refinement & 1 \\
\hline
\end{tabular}

It is the imitation of the operation of a real-world process or system over time. The act of simulating something first requires that a model be developed; this model represents the key characteristics or behaviors/functions of the selected physical or abstract system or process (5).

In this work, I have simulated failure based on bending stress and wear of the standard teeth of excavator bucket using ANSYS. ANSYS provides a wide range of affordable technologies and services to help meet the diverse and evolving needs for design. The reports generated by ANSYS on working excavator bucket are as follows: 


\section{International Journal of Science and Research (IJSR) \\ ISSN (Online): 2319-7064}

Index Copernicus Value (2013): 6.14 | Impact Factor (2015): 6.391

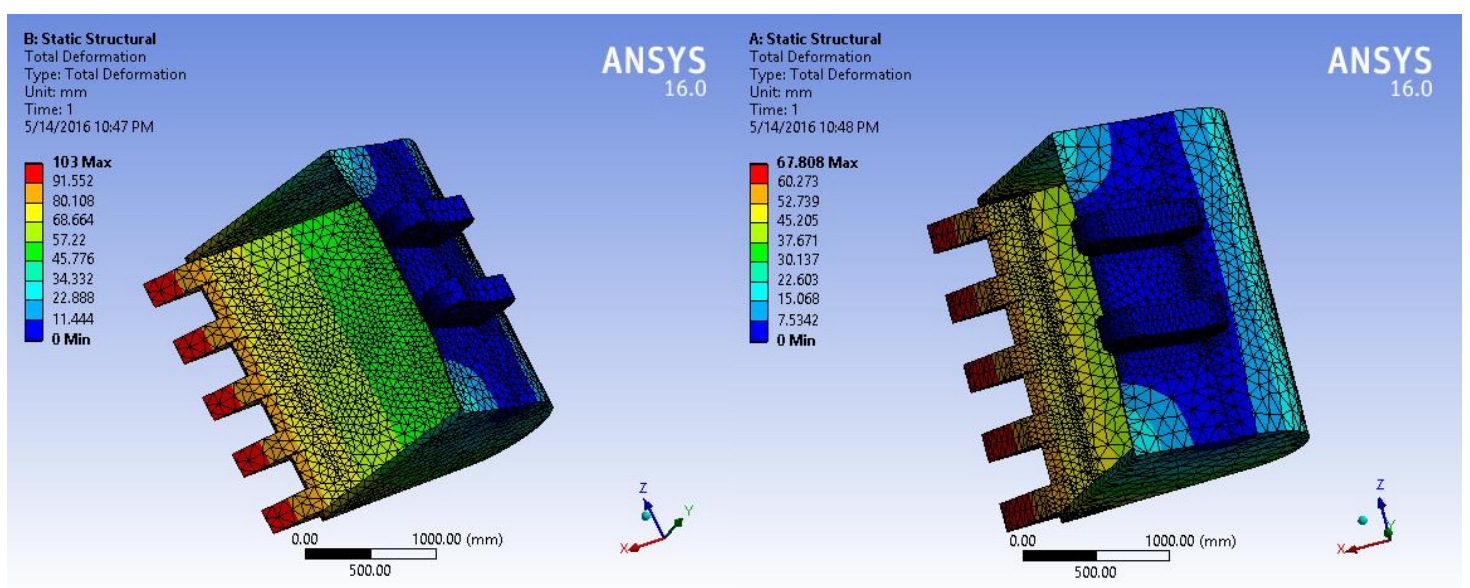

Figure 2: Total Deformation

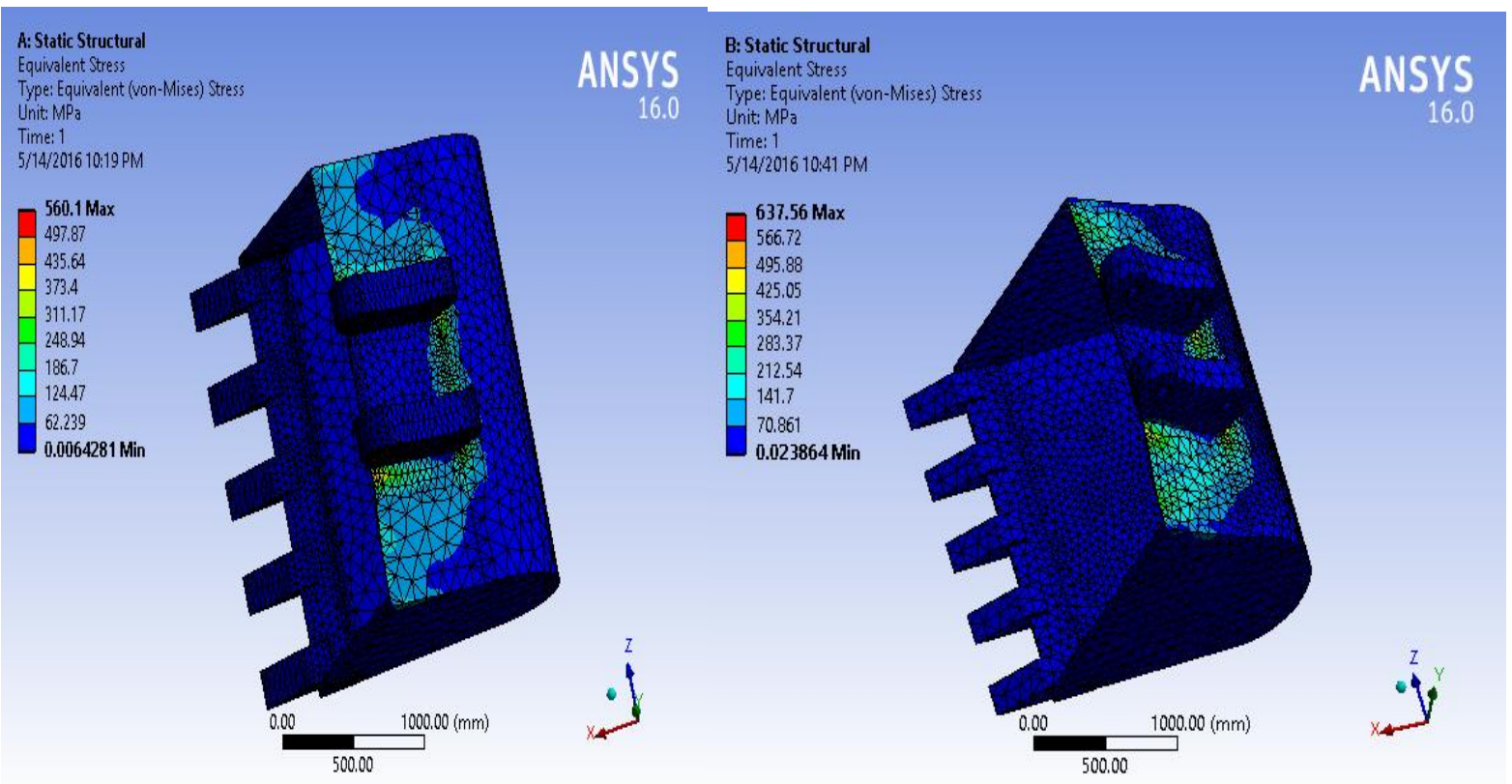

Figure 3: Equivalent Stress

Fig 2 represents the bending stress acting on excavator bucket tooth under $31900 \mathrm{~N}$ force.it is clear that maximum bending stress is acting in between the joint and bucket . Red portion represents the maximum bending stress which is equal to 560MPa for AISI1045 and 673.56MPa for AISI1035.

\begin{tabular}{|c|c|c|c|c|c|}
\hline Sno. & Material & Analysis & $\begin{array}{c}\text { Analytical } \\
\text { Result }\end{array}$ & $\begin{array}{c}\text { Ansys } \\
\text { Result }\end{array}$ & $\begin{array}{c}\% \text { of } \\
\text { Error }\end{array}$ \\
\hline 1 & AISI1035 & Bending stress & $511.76 \mathrm{MPa}$ & $497.87 \mathrm{MPa}$ & 2.72 \\
\hline 2 & AISI1045 & Bending stress & $511.76 \mathrm{MPa}$ & $495.88 \mathrm{MPa}$ & 3.10 \\
\hline
\end{tabular}

\section{Conclusion}

1) It is observed that the region near the bush and teeth are having high value of stress and hence they are more prone to failure.

2) Material will be separated if applied stress exceeds ultimate tensile stress.

3) Total deformation for AISI 1035 and AISI 1045 are 103 $\mathrm{mm} \& 63.08 \mathrm{~mm}$ respectively.it is clear that material AISI 1045 is stronger than material AISI 1035.
4) In field trial it was observed that teeth number $2,3 \& 4$ wear at faster rate than teeth 1 and 5 which is consistent with more material flowing over and around the outside teeth.

5) It is clear that percentage error of bending stress for AISI 1045 is approx. $3.10 \%$ and for AISI 1035, it is 2.72 $\%$ which is less than $5 \%$ hence our analysis is correct.

6) The position of middle tooth must be changed periodically so that uniform wear occur on each tooth.

7) The viability of the use the creep strain to model the wear coefficient for abraded materials was demonstrated. Previous models were developed taking into account only the Young's modulus of worn surface, discarding the properties of abrasive material. These cases work only for pairs where the abrasive particle is harder than the abraded material and it was demonstrated that they fail when the abrasive hardness is relatively low.

\section{References}

[1] "Mineral and Mining Industry in India January, 2010" http://www.azom.com/article.aspx?ArticleID=6540

[2] Eyre, T. S., 'Wear Mechanisms, Powder Metallurgy, 1981, 24(2), 57-63. 


\section{International Journal of Science and Research (IJSR) \\ ISSN (Online): 2319-7064}

Index Copernicus Value (2013): 6.14 | Impact Factor (2015): 6.391

[3] Archard, J. F. and Hirst, W. "Wear of metals under unlubricated conditions." Proceedings of the Royal Society of London. Series A, Mathematical and Physical Sciences, Vol. 236, No. 1206. (Aug. 2, 1956), pp. 397410.

[4] J. Banks, J. Carson, B. Nelson, D. Nicol (2001). Discrete-Event System Simulation. Prentice Hall. p. 3. ISBN 0-13-088702-1.

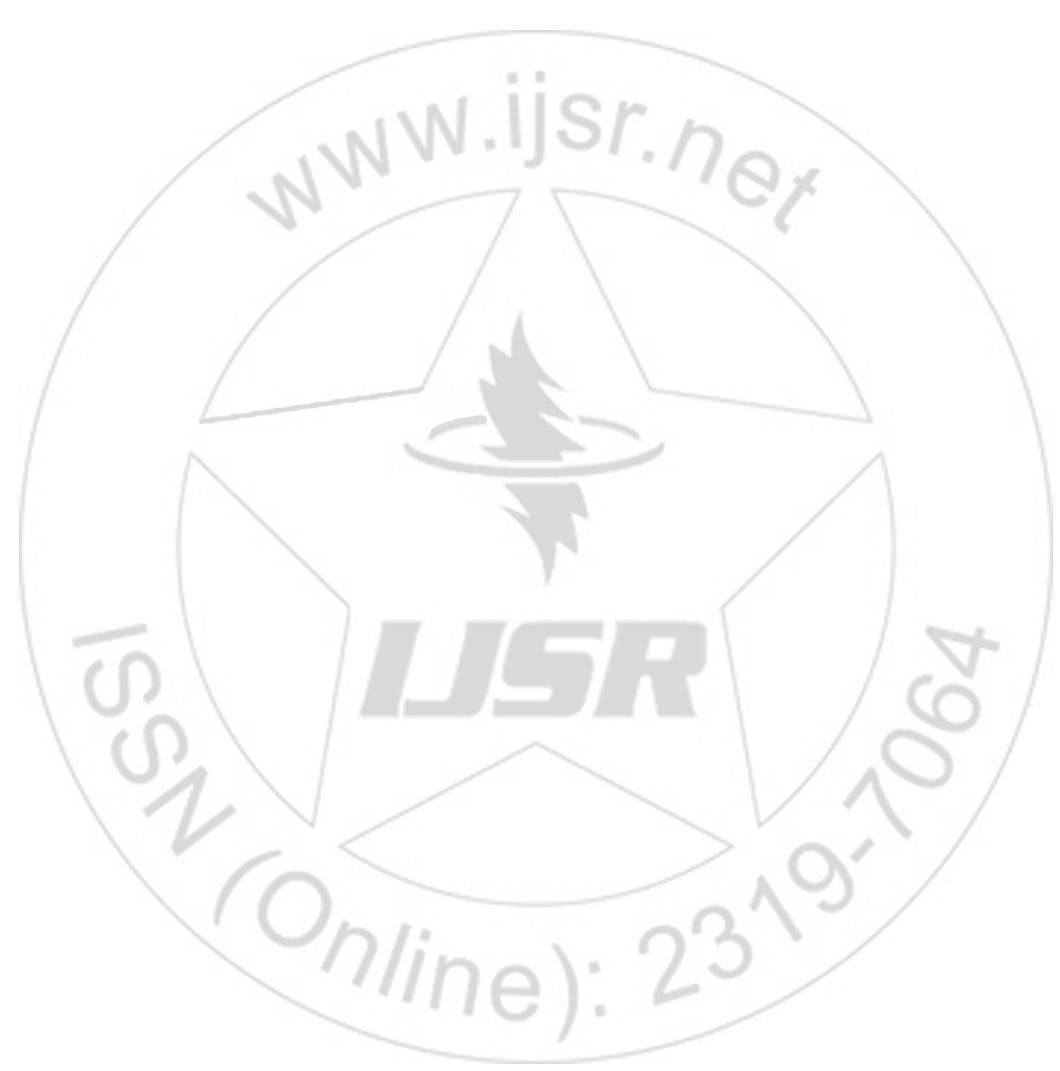

Volume 5 Issue 5, May 2016 www.ijsr.net 